\title{
'The right and the smart thing to do?' The Clinton administration and the social construction of emergency in the Kosovo crisis
}

\section{Andrea Betti}

To cite this article: Andrea Betti (2017): 'The right and the smart thing to do?' The Clinton administration and the social construction of emergency in the Kosovo crisis, The International Journal of Human Rights, DOI: 10.1080/13642987.2017.1383240

To link to this article: http://dx.doi.org/10.1080/13642987.2017.1383240

曲 Published online: 06 Oct 2017.

Submit your article to this journal $₫$

Q View related articles $\sqsubset$

View Crossmark data ¿ 


\title{
'The right and the smart thing to do?' The Clinton administration and the social construction of emergency in the Kosovo crisis
}

\author{
Andrea Betti \\ Department of International Relations, Faculty of Human and Social Sciences, Universidad Pontificia Comillas, \\ Madrid, Spain
}

\begin{abstract}
The lack of an international authority capable of interpreting and enforcing international norms in a centralised way often leaves states, especially the most powerful, free to decide whether to recognise or reject the legitimacy of such norms. Therefore, in a decentralised system, the legitimacy and viability of norms crucially depend on whether states perceive them as consistent with their values and interests. Variations in state responses to international norms are often the results of debates that take place at the domestic level. By relying on a 'unit-level' constructivist approach, this article offers a qualitative analysis that traces back the genesis of a normative interpretation devised by the Clinton administration, which led the United States to invoke the legitimacy of the controversial and emergent norm of humanitarian intervention and to conduct an air strike campaign against the Federal Republic of Yugoslavia. This interpretation concerned the viability and legitimacy of the norm and found its origin in an exceptionalist view of the role of the United States in the post-Cold War international system.
\end{abstract}

\section{ARTICLE HISTORY}

Received 21 March 2017

Accepted 19 September 2017

\section{KEYWORDS}

Social constructivism; norm entrepreneurs; United States foreign policy; foreign policy analysis; humanitarian intervention

When the United States (US) used force against the Federal Republic of Yugoslavia (FRY) in March 1999, many members of the Clinton administration invoked the existence of a norm of humanitarian intervention (HI) that legitimised military action for both moral and security reasons. As President Clinton argued, it was not only the 'right thing to do', but also 'the smart thing to do, very much in our national interest'. 'This article analyses the domestic debate surrounding the US participation in NATO Operation Allied Force by showing how relevant domestic actors - primarily the presidency and the State Department - acted as norm entrepreneurs and produced an interpretation that led the US to support a norm that has been widely contested and was still emergent. The reasons for this interpretation are found in an exceptionalist view of the US role in post-Cold War international relations, which the Clinton administration considered as the best response for a rapidly changing and unpredictable environment. Interestingly enough, some elements of this vision, in particular those related to the necessity to

CONTACT Andrea Betti andrea.betti1909@gmail.com @ Professor, Department of International Relations, Faculty of Human and Social Sciences, Universidad Pontificia Comillas, Calle Universidad Comillas, 3-5, 28049, Madrid, Spain 
trump legal requirements with humanitarian motivations, would constitute some of the justifications for the subsequent war in Iraq, waged by the Bush administration only four years later.

Focusing on the domestic level in the study of state responses to international norms is important in order to understand the conditions for a state's acceptance or rejection of a given norm. Most studies have concentrated so far on processes of norm creation and development that take place at the international level by highlighting the importance of systemic variables in the study of international norms. Norms usually emerge and develop within international environments, such as international organisations. Nevertheless, their legitimacy and efficacy frequently depend on what states decide to do with them. Sometimes states actively invoke international norms, as in the recent case of the NATO operation against Libya in 2011, while at other times they ignore them, as in the case of President Barack Obama's reluctance to intervene in the Syrian conflict. Norms on HI - later re-conceptualised in terms of the Responsibility to Protect (R2P) as an attempt to make them more acceptable internationally ${ }^{2}$ - usually find support, although in a quite erratic way, among Western countries, but also have different degrees of opposition among non-Western countries. Lacking a worldwide consensus, the interpretation of these norms essentially rests with states, which enables leaders and domestic institutions to act as 'norm entrepreneurs', 3 shaping their meaning and contributing to their pre-eminence or decline.

Several authors have located the explanation of US intervention in Kosovo at the international level by, for example, focusing on the impossibility to find a consensus at the Security Council or on the necessity to revitalise NATO after the Cold War. ${ }^{4}$ These explanations are relevant for the comprehension of the issue but have partially disregarded the US domestic debate on HI, which not only shaped US foreign policy in the Balkans at that specific moment but also provided normative arguments that can expand our understanding of previous and subsequent US military interventions.

Other approaches have focused on processes of states' interpretation of international norms and showed how relevant domestic constituencies can determine incorporation or rejection of international norms. ${ }^{5}$ Nevertheless, international norms can provoke different reactions that can change over time. For example, both the British government and the parliament adamantly supported HI during the Kosovo crisis, while they refused to use force for humanitarian reasons in the Syrian context. Miles Kahler has observed that recognition of norms can recede or consolidate because it often depends on contingent conditions. ${ }^{6}$ Domestic actors can modify their interests and ideas over time and decide to question the legitimacy of a norm that had been previously accepted. Between 1998 and 1999, the presidency and the State Department put forward an interventionist' interpretation of the Kosovo crisis that was based on the decision to prioritise an emerging and contested norm over the letter of existing international law, which the administration considered inadequate when solving humanitarian crises in the post-Cold War system.

By drawing hypotheses from the literature on social construction of norm internalisation, this article compares the role of the executive leadership with the contribution of two other types of domestic actors, lawmakers and civil society movements. Contrary to the expectations of various foreign policy analyses, both types of actors were marginalised during the process of interpreting the norm, which was mostly left to prominent 
individuals within the Clinton administration. On the one hand, the article contributes to the literature on domestic determinants of US foreign policy by showing the decisive role of executive actors during processes of interpretation of international norms and institutions. On the other hand, it contributes to the social constructivist literature on processes of norm entrepreneurship by showing how powerful political leaders acting within relevant executive platforms are in a privileged position to shape the interpretation of norms that are still in an emergent international status.

\section{Methodology}

In order to trace back the genesis and consolidation of this interpretation, I rely on a qualitative analysis of a crucial 'historical juncture" ${ }^{7}$ - the US intervention in Kosovo - on the basis of an interpretivist epistemology. ${ }^{8}$ I examine the meanings that relevant domestic actors assigned to the norm during the crisis and the reasons behind the positions taken by the Clinton administration. Along these lines, I develop a 'detailed narrative's of the competing interpretations of the norm in the US context and suggest an explanation of this process. Even though it does not promise to identify causal mechanisms that can be easily generalised, this methodology allows us to reconstruct the reasons for the process by testing a set of hypotheses from the relevant literature. ${ }^{10}$

In terms of techniques, I rely on the 'document analysis' of a large variety of official documents by examining their content, the context in which they were produced ${ }^{11}$ and the way in which domestic actors argued about them, ${ }^{12}$ which allowed the identification of some key issues that structured the debate and constituted the main argumentative resources of the actors involved. In terms of sources, I have relied on official documents produced by:

- The Clinton administration: policy documents, contributions to the legislative debate, press statements

- Congress: congressional proceedings and minutes of the relevant committees

- Civil society movements: reports, executive memorandums and contributions to the legislative debate

Moreover, I have conducted an in-depth analysis of the speeches given by President Clinton and the main members of the administration, which shed light on the way executive actors presented their arguments in favour of or against the norm and allowed the identification of recurrent key concepts ${ }^{13}$ that informed and shaped the interpretation provided by the administration, such as interdependence, democratic enlargement, and assertive humanitarianism.

\section{The Clinton administration and intervention in Kosovo}

During the second Clinton administration (1996-2000), the US official that was most committed to the Kosovo issue was Secretary of State Madeleine Albright. ${ }^{14}$ In this initial phase, she had to face scepticism from the Department of Defence, which did not view possible intervention in the region favourably. 
The interventionist camp acquired credibility in summer 1998 when Milosevic's forces started a campaign against Albanian villages in Kosovo. As a result, on 23 September 1998, the UN Security Council passed Resolution 1199, which demanded that the FRY 'cease all action by the security forces' and 'enable effective and continuous international monitoring, ${ }^{15}$

In October 1998, NATO approved an Activation Order that constituted an explicit threat to resort to air strikes in case FRY did not comply with Resolution $1199 .{ }^{16}$ The order convinced Milosevic to conclude a new agreement with US Special Presidential Envoy to the Balkans Richard Holbrooke. Nevertheless, Milosevic only accepted its conditions as a formality, and hostilities quickly reignited.

The massacre of Racak on 15 January 1999, when Serb militias killed 45 civilians in a small village in Kosovo, strengthened the arguments in favour of intervention. From that moment on, the administration elaborated an interpretation of the situation and the international legal system that led to the invocation of a right to intervene in order to resolve major humanitarian crises. After the failure of a last-ditch attempt to reach an agreement between Serbs and Kosovars in Rambouillet between February and March 1999, NATO countries approved military intervention. Even though the Security Council never authorised the use of force against the FRY, the Clinton administration considered that a superior 'logic of emergency' required NATO countries to enforce human rights in the name of the international community.

\section{Domestic systems and international norms}

Neorealism and neoliberalism have traditionally disregarded the impact of immaterial and domestic factors in international politics by focusing on the distribution of material capabilities and on the assumption of rational unitary actors. ${ }^{17}$ Some realists have recently challenged these assumptions by focusing on unit-level and immaterial variables, such as shifts in domestic preferences, perceptions, and domestic institutions. ${ }^{18}$ Despite these developments, constructivists have recognised a greater possibility of collaboration with liberal approaches, although some of them are still based on rational assumptions, ${ }^{19}$ and with classic realists, especially for their capacity to include domestic variables and immaterial factors, such as norms and ethics, in the analysis. ${ }^{20}$ However, constructivism still differs from traditional approaches, especially with regard to the conceptualisation of interests and identities that are constantly subject to transformation through the interaction between actors and material and immaterial structures. ${ }^{21}$

Nevertheless, even constructivist scholarship has been criticised for focusing primarily on the study of international structures ${ }^{22}$ and for disregarding the idea that 'norms and social understandings [have] different influences on different agents'. ${ }^{23}$ For this reason, this article relies on a 'unit-level' constructivist approach, with the goal of including the domestic sources of state identities in the analysis and of avoiding conceiving international politics as mostly the result of the international interactions among units. ${ }^{24}$ Actors can react differently to international norms, for example as 'a function of domestic structures'. ${ }^{25}$ The necessity to take agency into account has led constructivists to integrate its research frameworks into the literature on domestic determinants of foreign policy, which has explored the capacity of relevant domestic actors to influence foreign policymaking. ${ }^{26}$ 
For example, in The Power of Human Rights, the contributors have explored how states can react differently to similar human rights norms and how domestic arrangements, powerful leaders or organisations can favour or limit these processes. ${ }^{27}$ Nevertheless, these studies have especially focused on cases of developing states in which domestic actors have compelling reasons to incorporate human rights standards, such as the threat to have economic assistance terminated. The first step of their model of norm internalisation is 'adaptation and strategic bargaining', which reflects situations in which acceptance of norms is almost a matter of international survival. However, in a world in which power is unequally distributed, it is useful to study the impact of norms also on powerful states, which typically face fewer international constraints during processes of domestic incorporation of norms.

This article does not aim to deny that states also interpret norms depending on their material interests. For example, James March and Johan Olsen have suggested one way to measure the reasons for state behaviour along the distinction between logic of consequences' and 'logic of appropriateness'. ${ }^{28}$ The problem is that it is difficult 'to determine whether those who conform to a particular norm do so because they believe the norm is just ... or because adherence to the norm coincides with their other principal interests' ${ }^{29}$ States can always argue that a certain decision was made for humanitarian reasons or to pursue a certain material interest. Distinguishing the two dimensions can lead to several problems in terms of searching for evidence and operationalising impact. For this reason, it seems more useful to start from the observation that international norms generate political debates on their legitimacy that usually take place at the domestic level and whose conclusions can generate an array of different postures, from support to rejection.

\subsection{The choice of domestic actors}

As John Peterson has argued, various examples, from compliance with international agreements to acceptance of international institutions, can be made to show that often 'domestic institutions determine how states behave internationally' ${ }^{30}$ Nevertheless, many actors may be potentially relevant for an analysis of foreign policymaking. I have based my choice on two bodies of literature: the first on processes of state internalisation of norms and the second on domestic determinants of foreign policy.

First, while participating in foreign policy debates, political parties can act as 'domestic vehicles of international norms ${ }^{31}$ and shape state attitudes towards those norms. Focusing on party politics represents a strategy to solve problems of operationalisation that can be related to using more indeterminate concepts, such as identity or culture. ${ }^{32}$ I examine parties as the transmitters of the political ideas and arguments that distinguish domestic political systems at particular points in time.

Second, a significant part of the literature has explored the role of civil society. At the beginning, it dedicated particular attention to the impact of media and public opinion. ${ }^{33}$ Scholars have, for example, explored the 'CNN effect' as a phenomenon that can put pressure on governments to authorise military interventions. ${ }^{34}$ Media and public opinion are important actors in the study of foreign policymaking. However, assessing their impact can at times be difficult. There are a few polls available that tested the opinion of the US public during the Kosovo debate but they do not provide enough evidence to argue that public opinion had a recognisable impact on the issue. ${ }^{35}$ 
Due to these limitations, many scholars have preferred to focus on other societal actors, especially advocacy movements and think tanks. ${ }^{36}$ Often organised in transnational coalitions, these movements can raise awareness and sponsor solutions that help states implement standards of behaviour. I focus on the organisations that were most active before and during the Kosovo intervention, with an emphasis on those that were invited to the meetings of the relevant congressional committees.

Third, scholars of foreign policy analysis have pointed to executive leaders as crucial actors in the implementation of foreign policy decisions. ${ }^{37}$ Constructivists have also taken this hypothesis into account by highlighting the importance of leaders as 'norm entrepreneurs', who can call 'attention [to] ... or even "create" issues by using language that names, interprets, and dramatizes them' ${ }^{38}$

\subsection{International norms and domestic interpretation}

During domestic debates on international norms, executive leaders, social movements and lawmakers all produce arguments to shape specific interpretations, which concern the legitimacy of the norms and their capacity to resonate with the political discourse of a country at a particular moment.

Constructivists have conceptualised norms as collective frameworks commanding standards of proper behaviour and subject to wide-ranging debates on their legitimacy. Peter Katzenstein defines norms as 'collective expectations for the proper behaviour of actors with a given identity', meaning that they not only 'specify standards of proper behaviour', but also 'define the identity of an actor'. ${ }^{39}$ Second, the article focuses on the collective and shared nature of norms, which differentiates them from other immaterial structures, such as ideas. If ideas are conceptualised as 'beliefs held by individuals', ${ }^{40}$ norms are, rather, defined as 'collectively held ideas about behaviour' ${ }^{41}$ in the sense that they provide prescriptions about what must and must not be done. Finally, as Antje Wiener suggests, 'Norms are contested by default', especially when they are debated outside their 'socio-cultural context of origin'. ${ }^{42}$ For instance, when norms on HI reach the domestic system, they are likely to cause extensive debates about the legitimacy and convenience of committing national military resources to the securing of human rights.

This article analyses the US response to one particular manifestation of HI. Using force against FRY is not necessarily a synonym of recognising the legitimacy of HI. Nevertheless, the choice is motivated by the necessity to operationalise state response by focusing on an 'historical juncture' in which the norm was extensively debated and interpreted.

Moreover, several jurists and policymakers have debated whether, at the time of the Kosovo crisis, there existed a norm of $\mathrm{HI}$ at all. On the one hand, some admitted that the NATO operation constituted a breach of international law, due to its lack of UN authorisation, but also interpreted HI as a 'norm-in-progress', according to which, in cases of mass atrocities, the international community has a justifiable reason to intervene as a last resort based on imperatives that cannot find obstacles in the bureaucratic inefficiency of the Security Council. ${ }^{43}$

In contrast, other scholars have argued that invoking moral imperatives would be a 'subversion of international law'. ${ }^{44}$ Arguments in favour of the emerging nature of the norm ignore the lack of opinio juris, with states like China, Russia, and India opposing intervention in Kosovo. ${ }^{45}$ Scholars belonging to the English School reinforced these 
arguments by noting that the contemporary international system is still based on the ethics of state sovereignty, with the principle of non-intervention as its most important corollary. ${ }^{46}$

The debate generated so many controversies that a group of scholars and policymakers elaborated the notion of R2P to devise a less controversial conceptualisation of intervention. Alex Bellamy has recently argued that some elements of R2P, such as a state's responsibility for the well-being of its citizens, can be already considered legal norms recognised by most governments. ${ }^{47}$ However, this article does not aim to solve the problem of the legality of HI. The existence of a debate both in academia and at the UN level indicates that some actors, especially in the West, already considered HI as an emergent norm at the time of the NATO operation. As Risse, Ropp, and Sikkink observed, 'emergent international norms are often signalled by international declarations or programmes of action from international conferences' ${ }^{48}$ HI mostly fell short of the standards to be considered a legal norm. However, due to the practice of some states and the sympathetic attitude of some sectors within the $\mathrm{UN}^{49}$ one can argue that at the time of intervention in Kosovo, HI was a normative framework that some international actors considered to be in an emerging status, while others contested it. Given its status, the norm was exposed to the favourable and opposing interpretations of individual states.

\section{Disarmed voices: US civil society and Kosovo}

Various studies have recognised the capacity of civil society movements to influence foreign policymaking, especially in a pluralist political system like the US. ${ }^{50}$ Nevertheless, analysis of the US debate on the Kosovo crisis has not accorded a relevant role to these movements. With few exceptions, their impact on the process of interpretation of $\mathrm{HI}$, was limited and incapable of influencing the debate about using - or not using - force. This section focuses on the activities of the groups that produced the largest quantity of statements on the issue and that were most frequently invited to the hearings of the relevant legislative committees.

To include public opinion in this analysis, one should focus on the polls conducted on the issue. For example, the Program on International Policy Attitudes presented interesting conclusions, such as that the majority of Americans were 'uncomfortable about intervening ... without a UN Security Council Resolution, but most favor proceeding nonetheless' ${ }^{51}$ Nevertheless, the study was conducted several weeks after the decision to intervene, and most questions dealt with issues not directly related to the interpretation of the norm, such as whether or not to use ground troops, or the public's tolerance of potential casualties. Thus, there was not enough evidence to argue that public opinion influenced the debate.

Humanitarian organisations, such as Amnesty International (AI) and Human Rights Watch (HRW), maintained their traditionally neutral approach and did not propose any specific solution about the political or military instruments to be employed in the crisis. Moreover, they refused to side with one or the other faction in the conflict. In June 1998, AI stated that 'both sides of the conflict are accountable', ${ }^{52}$ meaning that both Kosovars and Serbs needed to be investigated for human rights violations. In a similar vein, when NATO and the UN invested the OSCE Verification Mission with the task of monitoring the situation, HRW recommended the mission not only 
'monitor, report, and publicize abuses committed by the security [Serb] forces', but also '[Kosovo Liberation Army] abuses'. 53

This approach was maintained during the NATO operation as well, when AI denounced the fact that 'insufficient consideration may have been given to the proximity of civilians in NATO's planning of the attack'. ${ }^{54}$ At the basis of these critiques, there was the idea that complex humanitarian crises should be solved through a non-confrontational approach centred on a preference for non-violent instruments of intervention, such as 'independent human rights monitoring, ${ }^{55}$ In so doing, both AI and HRW remained loyal to their mission, but also partially excluded themselves from the debate on the use of force to avert humanitarian violations. Their interpretation of the issue was rooted in a conception of the international system according to which military force is not effective at promoting human rights. As a consequence, their contribution to the debate on the emerging norm of $\mathrm{HI}$ was limited.

In a different fashion, several think tanks took stances during the crisis, but essentially failed to develop a clear interpretation of events. This was, for example, the case of the conservative American Enterprise Institute (AEI), which put forward arguments both in favour of and against intervention. On the one hand, during a debate before the House Committee on International Relations, Jeane Kirkpatrick supported the NATO operation by arguing that 'sovereign rights of government are related to their legitimacy' ${ }^{56}$ This meant that NATO countries had the right to intervene even in the absence of a Security Council resolution. On the other hand, AEI's Vice-President, John Bolton, criticised President Clinton by asserting that US decisions on the use of force should only be based on national interests - which in the case of Kosovo were 'tenuous at best ${ }^{57}$ - and not on 'malleable' principles of international law 'especially susceptible to cynical manipulation' ${ }^{58}$ In sum, Kosovo triggered different positions inside AEI, which, as a result, was unable to produce an effective action of lobbying towards the administration.

Other think tanks developed more coherent stances in favour of or against intervention, but their contributions tended to remain isolated, with many of their arguments reaching the debate only after the administration's decision to bomb Belgrade. Two think tanks that are generally sympathetic to the Republican Party contested the rationale for intervention. In October 1998 the Heritage Foundation recommended avoiding another 'open-ended Balkan commitment'. ${ }^{59}$ Military involvement in the region was going to be 'costly and protracted' and 'would undermine the ability of the United States to meet vital security obligations elsewhere'. ${ }^{60}$ Along similar lines, Doug Bandow of the Cato Institute argued that intervention 'could put U.S. troops at risk without having any serious ... American interest at stake'. ${ }^{61}$ At the basis of these arguments was a realist understanding of the US international role, which could not afford to act as a 'global policeman with endless involvement in far-flung conflicts'. ${ }^{62}$

The Cato Institute was among the few to criticise the legitimacy of the intervention. Several months before Operation Allied Force, Gary Dempsey argued that 'states are sovereign entities that have exclusive jurisdiction over matters within their borders' ${ }^{63}$ These arguments had the potential to undermine the policies of the administration, which was basing the justification of intervention on the idea that some superior moral values exist which can at times justify a partial suspension of international law. Nevertheless, Cato was quite isolated in criticising the administration's attempt to supersede traditional international law. Most conservative opposition coming from civil society 
preferred to base its analyses on traditional concepts, such as the lack of US interests in the region. This did not facilitate the development of a critique that could influence the process of interpretation of an emergent international norm.

Finally, not even the arguments in favour of intervention had much chance to influence the debate. The most active group was the Albanian American Civic League (AACL). Since the beginning of 1999, AACL had lobbied the US Congress by harshly criticising the attempts to find a diplomatic solution to the crisis: 'One must ask why our State Department is allowing a chauvinistic and dictatorial pan-Slavic Orthodox regime ... to emerge in the Balkans. ${ }^{64}$ The AACL often disagreed with the administration, such as in the case of the Rambouillet talks, which they considered a waste of time, and above all, on the issue of the possible independence for Kosovo. Very few US officials considered independence a viable option during the 1998-1999 crisis. As a consequence, representatives of the AACL were rarely invited to the relevant legislative committees and their arguments did not trigger any significant debate. ${ }^{65}$

The think tank that most clearly advocated intervention was the Brookings Institution. Through its leading scholars, Brookings developed a political stance in favour of HI, understood as a necessary step to improve an obsolete international legal order. For example, Ivo Daalder rejected complaints about the lack of a legal basis, by stressing that 'the insistence on a UN mandate implies that ... the widespread abuse of human rights and denial of fundamental freedoms would go effectively unpunished'. ${ }^{66}$ These arguments touched upon the legitimacy of $\mathrm{HI}$ and constituted significant contributions to its domestic recognition. Nevertheless, most meetings and publications came out only after the start of hostilities. Most of them were retroactive manifestations of support for a process that had been already completed with the decision to bomb the FRY.

Despite some exceptions, civil society movements did not significantly influence the debate on the legitimacy and viability of HI. Humanitarian non-governmental organisations maintained their traditional neutral approach without suggesting any political or military solution. Some think tanks provided different and sometimes contradictory stances, and were unable to develop unambiguous positions. Others had few occasions to partake in the debate, or limited themselves to subsequent manifestations of support.

\section{The confused assembly: US Congress in the Kosovo crisis}

According to a significant part of the literature, political parties participating in foreign policy debates can shape the position of a country towards international norms. ${ }^{67}$ Nevertheless, this was not the case during the Kosovo crisis. On the one hand, the debate created intra-party splits, rather than falling along partisan lines; this prevented the Republican majority from exerting any real influence on the positions of the administration. On the other hand, Congress acted in a confused way, with legislators mostly incapable of developing clear positions that could influence the administration's actions.

This analysis does not neglect the fact that Congress often has the capacity of influencing US foreign policymaking, for example on international treaties. ${ }^{68}$ However, in the case of Kosovo, invocation of HI was accompanied by the decision to wage war against another state. Several studies have highlighted how US executive actors tend to be predominant during decision-making processes that imply the use of military force. ${ }^{69}$ Moreover, the Kosovo debate centred on the interpretation of an emergent norm, which was neither 
codified in a precise international treaty nor engrained in an international custom. In this sense, it was difficult for Congress to express a position on a mostly undefined issue, which favoured the predominance of the administration in the process.

\subsection{A chaotic bipartisan debate}

The dynamics of party politics, which have acquired importance in US foreign policy especially after the end of the Cold War, ${ }^{70}$ did not influence the Kosovo debate in a relevant way. The main arguments provided by legislators in favour of or against intervention did not follow clear party lines. Many prominent members of the Republican Party, which held a majority in both houses of Congress at the time, often sided with Democrats in supporting intervention during crucial moments of the crisis. Similarly, various members of the Democratic Party sided with those Republican legislators that opposed the rationale for the operation.

Thanks to the victories during the 1998 midterm election, Republicans managed a majority of 12 seats in the House and 10 seats in the Senate. This political circumstance, together with the involvement of the president in the Lewinsky scandal, 'presumably provided the conditions for a more assertive Congress. ${ }^{71}$ With the Republican Party controlling both the House and the Senate, a partisan debate over Kosovo could have at least partially influenced the administration's strategy of intervention.

At the start of the debate, Congress was sympathetic to the situation of Kosovars, with Republicans and Democrats united in arguing that the US 'cannot and will not tolerate another Bosnia in the Balkans, ${ }^{72}$ When the possibility of using force became an option in autumn 1998, disagreements soon materialised. First, Congress debated whether intervention could be carried out in the absence of a Security Council Resolution. Second, US legislators discussed whether congressional authorisation was necessary before taking action.

In both the Democratic and the Republican parties, a majority of representatives based their arguments on a mix of moral considerations and national interests to support intervention. Bipartisan consensus was particularly evident in the Senate. In summer 1998, Democrat Joe Biden argued that 'the continuing fighting threatens the stability of neighbouring Albania and also of the former Yugoslavian Republic of Macedonia'. ${ }^{73}$ In a similar way, Republican John McCain noted that 'the prospects are quite real that [conflict] may eventually embroil other countries in the region'. ${ }^{74}$ Positions were also quite similar as to the moral logic behind intervention. For example, the Chairman of the House Committee on International Relations Republican Benjamin Gilman reminded the public a few hours before the intervention that the NATO operation had the aim 'to end Milosevic's brutal attacks upon the Albanian population of Kosovo' ${ }^{75}$

Bipartisan arguments were especially directed against those who subjected the legitimacy of the operation to an affirmative vote by the Security Council. In October 1998, Democrat Eliot Engel argued that 'the United Nations does not have a veto on what we can do'. ${ }^{76}$ Many senators equally rejected the centrality of UN procedures. For Republican John Warner, 'in no way should the United Nations ... have any veto over the decision of the collectivity of nations ... to take such action as they deem necessary to bring about a cessation of the tragic situation in Kosovo. ${ }^{77}$ Pointing out that an excessive search for UN authorisation would mean the possibility of China and 
Russia vetoing US foreign policy, Biden concluded that the US had to be 'prepared to act alone if necessary'. ${ }^{78}$

The bipartisan character of the debate was also evident in the arguments against the operation. Despite their differences, they were all characterised by a substantial rejection of the 'emergency logic' spelt out by the administration, which circumvented international and domestic law. In October 1998, Republican Thomas Campbell and Democrat David Skaggs sent a letter to President Clinton arguing that 'the Constitution says that we do not go to war unless the representatives of the people... vote for it'. ${ }^{79}$ Along these lines, Republican Ron Paul criticised intervention on the basis that 'the President cannot send these troops without congressional approval'. ${ }^{80}$

It was during the hearings of the House Committee on International Relations that opponents to the operation developed their anti-interventionist discourse. Campbell reiterated that attacking FRY should be treated as an 'act of war' subject to Congressional approval. Moreover, NATO was waging war against a sovereign state without having been attacked first and without UN authorisation. ${ }^{81}$ Representatives with different backgrounds and ideological positions shared these arguments. For example, near the end of hostilities, Democrat Barbara Lee pointed out that with Operation Allied Force, US Congress had 'abdicated [its] Constitutional responsibility'. ${ }^{82}$

The Senate was generally more sympathetic towards intervention, but instances of opposition also presented this bipartisan character. Republican Arlen Specter often asserted that air strikes constituted an act of war and that 'only Congress has the constitutional prerogative to authorize war' ${ }^{83}$ These ideas found the support of Democrat Russ Feingold, who opposed intervention both because it gave too much authority to the president and because of the lack of clear interests in the region. ${ }^{84}$

In conclusion, the operation created divisions more within rather than between parties. The debate was shaped by the 'presence of a number of moderate Republicans with strong foreign policy credentials, coupled with Democrats who wanted to use force' ${ }^{85}$ In a similar way, opposition was not identifiable with one party or the other, but could be found among both Republicans and Democrats. In this political context, bipartisan support and opposition materialised as almost accidental results, and not as the outcome of specific policies pursued by the two main parties.

\subsection{A muddled legislative action}

Until the beginning of 1999, Congress was not particularly active on the Kosovo issue, and was limited to condemning Serb violence. ${ }^{86}$ Despite a few bipartisan inquiries on the legality of intervention, ${ }^{87}$ the administration pursued its strategy without encountering any major obstacle from Congress. As an indicator of the inability of Congress to influence the interpretation of $\mathrm{HI}$ and the planning of the military operation, the main attempts to constrain the actions of the administration came after the start of hostilities. As a commentator observed, 'lawmakers debated the wisdom of the Kosovo mission virtually up to the time that the air strikes began'. ${ }^{88}$ On 23 March, the Senate passed a bipartisan resolution sponsored by Biden (D-DE) and Warner (R-VA), which stated that 'the President of the United States is authorized to conduct military operations and missile strikes' ${ }^{89}$ The resolution was not legally binding, and amounted to a simple manifestation of support. War against FRY started without constitutional authorisation. 
During Operation Allied Force, some lawmakers dedicated themselves to enforcement of the 1973 War Powers Act, which provides that, without a declaration of war, the president is forced to gain congressional approval within 60 days from the start of the operation. ${ }^{90}$ Two resolutions, which were debated and voted on by the House on 28 April, seemed to indicate its intention to play a more assertive role. In fact, these debates led to contradictory results.

Republican representatives Tilly Fowler and William Godling sponsored Resolution 1569 to prohibit the possibility of deploying ground troops in Kosovo 'unless such deployment is specifically authorized by a law'. 91 This Resolution found bipartisan support, with 46 Democrats voting with the Republican majority, and was finally passed. Nevertheless, its significance was immediately defeated by another vote on the very same day. After more than one month from the beginning of hostilities, the House debated Resolution 21 , a concurrent resolution that authorised the president 'to conduct military air operations' against FRY. ${ }^{92}$ The same resolution had been passed by the Senate a few moments before the start of the operation in March. ${ }^{93}$ Surprisingly enough, the vote on Resolution 21 resulted in a tie (213-213). According to the rules of the House, this meant rejection. ${ }^{94}$ The House of Representatives did not authorise the administration to participate in NATO air strikes. The impact of this vote was non-existent, since it came after a month from the start of intervention. Rejection of Resolution 21 was a retrospective manifestation of opposition at a moment in which it would have been impossible to halt US aircraft. Moreover, it came after an affirmative vote by the Senate on 23 March, when the Republican majority, together with the Democratic Party, had shown no hesitation to authorise the operation. Stuck between the necessity to support US troops and the will to exercise its constitutional prerogatives, Congress followed a contradictory course of action.

This inconsistent attitude was also evident during the debate on the 'Kosovo and Southwest Asia Emergency Supplemental Appropriations Act' (HR 1664), which contained provisions to guarantee financial support for the operation. On that occasion, Republican Ernest Istook presented an amendment to make sure that 'no ground forces of the United States can invade Yugoslavia absent a declaration by this Congress'. As Istook clarified, the amendment was not meant to kill the entire Bill or stop the operation, but simply to give Congress the opportunity to exert some control over the use of ground troops in Kosovo. ${ }^{95}$ This amendment would have given teeth to Resolution 1569, which the House had passed only one week before, and which required that the administration gain congressional approval before committing ground troops. Nevertheless, the House went against its previous decision, and rejected Istook's amendment with only 97 Republicans supporting it. ${ }^{96}$

Various observers noted these contradictions and underscored how 'scores of Republicans who had cast mostly symbolic votes against air strikes ... only a week earlier changed their votes to support financing the war'. ${ }^{97}$ On the one hand, the affirmative vote for the Bill was a manifestation of responsibility by Congress, which could not fail to support US troops during a military operation. On the other hand, Congress was sometimes committed to limiting the room for manoeuvre of the administration, while at other times it refused to pass legislation that could have made these actions more effective. This signalled the inability of Congress to 'find its voice on the conflict'. ${ }^{98}$ 
Both the Republican and Democratic parties were incapable of expressing clear positions. Examples of congressmen that crossed party lines and supported the positions of the rival party became the rule rather than the exception. Despite some attempts, Congress essentially failed to exert its constitutional prerogatives on war powers, and missed the opportunity to influence the debate on HI.

\section{Shaping the legitimacy of a controversial norm: presidency and state department}

Despite domestic and international opposition, the US was one of the largest supporters of HI during the Kosovo crisis. The Clinton administration acted as a 'moral entrepreneur' and provided an interpretation of the international system and the situation in the Balkans that created the conditions for US support of an emergent norm surrounded by controversies. Through the actions of the presidency and the State Department, the administration embraced an 'interventionist logic', which was rooted in a vision of the role of the US in the international system that can be defined as exceptionalist, intended as a tendency to interpret international norms either as obstacles in the pursuit of legitimate goals or as resources to justify action.

Nevertheless, the planning of Operation Allied Force was not devoid of disagreements inside the administration either. At the beginning of the crisis, at least two different mindsets competed to determine the US position.

On the one hand, the defence community was quite reluctant about the possibility of getting involved in a humanitarian emergency. On the other hand, the State Department conducted diplomatic activities based on the conviction that US action could be effective only if accompanied by the threat to use force. Secretary of State Albright was the main representative of the latter mind-set. With a personal background characterised by political persecution against her family both by German Nazism and Czech Communism, Albright offered a moralistic approach to international politics 'with an emphasis on battling evil dictators' ${ }^{99}$ Occasionally, she did not hesitate to compare the Kosovo issue with the 1938 Munich Conference to remind the public that an appeasement with Milosevic was likely to produce severe consequences. ${ }^{100}$ However, in summer 1998, her position could only count on support from State Department officials, such as Deputy Secretary of State Strobe Talbott and Special Envoy to the Balkans Robert Gelbard. ${ }^{101}$

In this initial phase, the main opponent to the intervention was Secretary of Defence William Cohen, a moderate Republican. On several occasions, Cohen warned against intervening 'in areas where there is not an immediate threat to our vital interests'. ${ }^{102}$ The Chairman of the Joint Chiefs of Staff, General Hugh Shelton, expressed similar concerns about the risk of 'getting caught in the middle of a civil war'. ${ }^{103}$ Although opposition to intervention was mostly 'lurking rather than openly voiced', ${ }^{104}$ the administration witnessed several disagreements. The only member of the defence community who decidedly supported the necessity for intervention was General Wesley Clark, who criticised the 'military's innate conservatism' and pushed for a more proactive stance by NATO countries. $^{105}$

As the situation in Kosovo deteriorated, President Clinton increasingly supported Albright's position. In September 1998, for example, he warned that 'the threat of humanitarian catastrophe is becoming even more real'. ${ }^{106}$ In addition, events from the region played 
a decisive role in softening the resistance of the military community. The report of the killings of 45 civilians by Serb forces in the village of Racak increased the credibility of the interventionist camp. Racak reduced disagreements and created the conditions for a renewed commitment to solve the crisis. The same day, the administration approved a 13-page classified document known as 'Status-quo plus'. This document represented the 'highest common denominator' among members of the administration and prioritised the promotion of 'regional stability' in order to prevent 'a renewed humanitarian crisis' and preserve 'U.S. and NATO credibility'. ${ }^{107}$

Since the reluctance of the Pentagon about a long-term involvement was difficult to overcome, it fell to Secretary Albright to take action. After criticising the attempts to resist intervention, Albright and her staff worked on an ultimatum to both Serbs and Kosovars to accept an interim agreement. In the case of acceptance, NATO would deploy troops to enforce the agreements. In the case of rejection, NATO would start an air campaign against Serb militias. As Daalder noted, 'no one could come up with a better alternative', and President Clinton endorsed the proposal. ${ }^{108}$ This was the premise for the convocation of the Rambouillet talks in February 1999. Serb failure to accept the agreement dissipated any last doubts. From that moment on, the administration spoke with one voice and devoted itself to justifying the use of force and to defusing scepticism about its shaky legal basis.

\subsection{The post-Cold War international system}

The invocation of HI in Kosovo relied on an interpretation of the international system based on three main elements, which underlie an exceptionalist view of the US in international politics. This view is not a novelty in US history. ${ }^{109}$ Several scholars have emphasised how it has conditioned the relation between US foreign policy and international law, especially since the Cold War. On the one hand, it can be seen as the 'zeal to recast international society in the United States' domestic image' and to structure the world around liberal values. On the other hand, it can take the form of a 'determination ... to defend U.S. national interests, sovereignty and freedom of action against infringement by global rules and supranational bodies'. ${ }^{110}$ The latter attitude can be noticed both in relation to international human rights treaties, some of which the US has either ignored or openly opposed, ${ }^{111}$ and to warfare policies, with many military operations unable to meet domestic and international legal criteria for intervention. ${ }^{112}$

Through the argument that US intervention did not require either authorisation from the Security Council or a formal declaration of war by Congress, the Clinton administration similarly spelt out a form of 'exemptionalism'. ${ }^{113}$ Given the US's primary responsibility to maintain peace and security, the legitimacy of stopping massive humanitarian violations was seen as enough of a justification to bypass existing legal frameworks.

First, for the administration, the end of the Cold War and the process of globalisation created conditions of a 'dynamic and uncertain security environment replete with both opportunities and challenges'. ${ }^{114}$ The post-Cold War system was not necessarily more secure. In the 1997 National Security Strategy, the administration asserted that the US had to face dangers that were 'unprecedented in their complexity'. ${ }^{115}$ The Defense Department shared this view in its 1997 Quadrennial Review by identifying 'failed or failing states' as producers of instability and human rights violations in regions where the US 
had vital interests. ${ }^{116}$ In a world of interdependent threats and opportunities, the promotion of liberal values was considered consistent with the implementation of US interests.

This strategy had to be pursued through a policy of 'democratic enlargement'. ${ }^{117}$ As an updated version of democratic peace theory, the administration believed that 'countries whose citizens choose their leaders ... are less likely to threaten peace'. ${ }^{118}$ Fostering an international environment based on democratic and human rights was a precondition for US security. ${ }^{119}$ The implementation of these norms could only be accomplished through a combination of political, diplomatic and, when necessary, military resources.

Finally, the way to bring national interests and moral values together was found in a political formula defined as 'assertive humanitarianism'. ${ }^{120}$ This notion aimed to secure US interests through the selective and flexible enforcement of international values, especially human rights. The administration dedicated a policy document - Presidential Decision Directive 25 (PDD 25) - to explaining its conceptualisations of selectivity and flexibility. On the one hand, the memory of the Somalia fiasco, in which insufficient planning had led to the impossibility of solving the humanitarian crisis, required the establishment of a set of criteria to guide US participation in peace enforcement operations. Participation had to be limited to immediate threats to international security, among which the document listed 'gross violations of human rights'. ${ }^{121}$ Moreover, operations had to have 'clear objectives' and be tied to 'realistic criteria for ending the operation', based on the idea that the US could not be the world's policeman. ${ }^{122}$

On the other hand, flexibility meant that US interventions did not necessarily require a multilateral character. As National Security Adviser David Lake stated, 'only one overriding factor can determine whether the U.S. should act multilaterally or unilaterally, and that is American interests'. ${ }^{123}$ Along similar lines, the military community stressed that multilateral action was welcomed, but could not become an obstacle to the pursuit of US interests. $^{124}$ The administration made it clear that international and domestic legal requirements could not be invoked as restraints. Internationally, the UN was considered as a useful tool to 'defuse crises and prevent breaches of peace', but, at the same time, '[it] has not yet demonstrated the ability to respond effectively ... when military credibility is what is required'. ${ }^{125}$ Domestically, congressional authorisation could not be the decisive factor between intervention and non-intervention. As Lake pointed out, 'When Congress ... considers resolutions calling for an early withdrawal of our forces ... it undermines our objectives and it compounds the risk for our troops' ${ }^{126}$

The administration understood that, especially with regard to military affairs, existing international and domestic law could not be the primary elements determining the legitimacy of US foreign policy. Through this argument, the administration built a 'communicative consensus ${ }^{127}$ about its understanding of the situation in Kosovo, by presenting it as a paradigmatic example of the inadequacy of international and domestic law in dealing with new types of armed conflicts and violations of human rights.

\subsection{Superseding international and domestic law}

For the administration, the post-Cold War international system was characterised by exceptional situations in which the legitimacy of military action did not necessarily rest on its legal basis. Under circumstances of particular urgency, military action did not 
need to find its justification in a resolution of the Security Council or in a declaration of war by Congress. Rather, it was the urgent and exceptional character of the situation that provided the legitimacy for using force. Military intervention could be sometimes dictated by the duty to enforce human rights, while at other times by the necessity to defend security and defence interests. In both cases, its legitimacy rested on a superior logic that overrode the letter of international or domestic law.

Given the impossibility of receiving a legal justification at the Security Council, the administration acted as a 'norm entrepreneur' and prioritised an emergent and contested norm over traditional principles of international law - namely non-intervention and state sovereignty.

Emphasising the morality of military action was the starting point of the administration's logic of argument. The situation in Kosovo was described as 'an urgent matter' ${ }^{128}$ that required an intervention whose legitimacy was mostly located in its humanitarian purpose. Nevertheless, the moral dimension of military action was not the only element that required US involvement in the Balkans. As Undersecretary of Defense Walter Slocombe argued, intervention was 'essential for ... our ability to defend our interests around the world', which gave the US 'broad authority to act'. ${ }^{129}$ As a superpower with global interests, the US could not neglect an area of Europe that President Clinton often described as a 'tinderbox'. 130

The administration relied on both international justice and national interests as argumentation devices to interpret $\mathrm{HI}$ as a necessary norm for exceptional situations. This vested the US and NATO with the right and duty to override any national and international arrangements that could prevent or slow the resolution of the crisis. This argument characterised the administration since the beginning of the crisis. In July 1998, Slocombe asserted that while it is always better from the point of view of international support to have a U.N. mandate... [this] doesn't mean that it's essential'. ${ }^{131}$ Dealing with an exceptional situation, NATO could neither 'be subject to a requirement of Security Council action' nor to 'a veto before it could take action'. ${ }^{132}$

Interestingly enough, some members of the administration occasionally attempted to justify intervention by proposing a broad interpretation of Art. 51 of the UN Charter and the principle of self-defence. For National Security Advisor Sandy Berger, NATO action should be considered a response to 'threats to the stability and security of its areas'. ${ }^{133}$ The changing nature of threats to peace and security in the post-Cold War environment made it so that self-defence could not only be limited to responding to a previous attack. In this new environment, security could be affected in many other ways, including widespread violations of human rights. Assessing the legal validity of this interpretation is not the scope of this article. What is important to underscore are the political roots of this reasoning. For US leadership, the legitimate concern with a humanitarian crisis that could hinder the security of Europe provided a moral and political impetus to outweigh existing international law.

The administration applied a similar logic to explaining the domestic legal basis. In his responses to congressmen, Clinton often argued that the US president had the 'constitutional authority to conduct U.S. foreign relations ... as a Commander in Chief. ${ }^{134}$ This was consistent with the exercise of war powers of most administrations since at least World War I, but was also the result of an interpretation of the crisis in the context of a rapidly changing international system. For the administration, a declaration 
of war was unnecessary since the US was not 'at war with Yugoslavia or its people'. ${ }^{135}$ While carrying out an intervention that aimed to end violations of human rights and restore stability in the Balkans, the US and NATO were 'upholding the will of the international community. ${ }^{136}$ NATO action had to be more accurately described as a police operation, and not as a traditional war. The administration applied the same logic of emergency that characterised the entire process of invocation of HI. Domestic law could not become a straitjacket to US efforts to solve a humanitarian crisis.

The administration's various arguments - the moral duty to tackle the humanitarian crisis, the presence of crucial security interests, and the right of the presidency to exert its authority - all encompassed a broader and more fundamental logic: when emergency becomes the rule, as in the middle of a humanitarian catastrophe, derogating from existing international and constitutional law is not only possible, but also necessary. The legitimacy of military action takes precedence over its legality.

For several observers, the attitude to prioritise humanitarian concerns over legal requirements was already visible in previous US operations. For example, the 1991 intervention against Iraq was based on an explicit authorisation by the Security Council but not on a formal declaration of war by the US Congress, which simply voted for legislation that broadly authorised President Bush Sr to 'achieve implementation' of Security Council resolutions. ${ }^{137}$ Something similar can be argued with the air strikes carried out by the Clinton administration against Iraq between 1993 and 1998. Some legal experts initially advanced the argument that air strikes were lawful because they were carried out in exercise of the customary international law principle of humanitarian intervention'. Scholars such as Nicholas Wheeler more prudently spoke of a 'normative shift' because for the first time the international community recognised internal repression in a state as a threat to peace and security. However, as Wheeler also observed, the lack of opinion juris by a significant number of other states still highlighted the shaky legal basis of such operations. ${ }^{138}$

Even clearer according to other authors would be the link between Kosovo and the 2003 intervention in Iraq. Aidan Hehir has, for example, argued that Kosovo should be seen as the 'culmination of a decade of pressure by the U.S. and the UK against the legal framework of the Charter'. ${ }^{139}$ Even though it would be difficult to consider Iraq as a direct consequence of Kosovo, the two interventions are linked by a similar way of (mis)using humanitarian arguments in order to fill the gaps of a scant legal basis. Both Operations Iraqi Freedom and Allied Force failed to obtain the authorisation of the Security Council, while the former obtained Congressional approval. Nevertheless, as Fisher argued, Joint Resolution 114 of October 2002 could not be seen as a proper declaration of war because it simply 'transferred' the decision on whether to wage war to the president. $^{140}$

The main similarities between Kosovo and Iraq are to be found in the way the two different administrations argued about the right to intervene. Similarly to the Kosovo debate, President Bush based his justification on a mix of strategic and humanitarian motives. ${ }^{141}$ Nevertheless, the abuse of humanitarian arguments, together with the accusation of lying about Saddam Hussein's weapons of mass destruction, arguably undermined the legitimacy of HI in contemporary international relations. ${ }^{142}$ As the World Summit Outcome of 2005 shows, Iraq reinforced the lack of trust among Northern and Southern countries and further diminished the possibility to consolidate norms of $\mathrm{HI}^{143}$ 


\section{Conclusions}

The most influential US domestic actors during the process of interpretation of $\mathrm{HI}$ in the Kosovo crisis were located at the executive level, particularly in the presidency and the State Department. Executive leaders framed the crisis as a fundamental humanitarian and strategic concern, and contributed to providing an interpretation of HI that was consistent with their main views on the post-Cold War international system. These views were informed by an exceptionalist mindset that conceived the US as being exempted from international or domestic regulations that could prevent it from pursuing legitimate and useful goals.

Dealing with a norm that was poorly codified and in an emergent status, the administration acted as a norm entrepreneur, and determined the US position on this matter. Other domestic actors participated in the debate, but were unable to exert a significant impact. With few exceptions, civil society organisations could not develop a clear position on the use of force across state borders for humanitarian reasons. The role of lobbying that advocacy movements can usually play in the US decision-making process was limited.

Moreover, HI involved military issues, and did not warrant any particular legislation in order to be interpreted and implemented. This considerably limited the ability of Congress to influence the debate. On the one hand, Congress preferred to delegate a delicate war issue to the administration, in a way that has been consistent with the history of US war powers since the start of the twentieth century. ${ }^{144}$ On the other hand, the difficulty of engaging with a norm that was not enshrined in an international treaty, over which the Senate would have had the last say, significantly constrained the powers of the Republican-led Congress. On other occasions, the same Congress did not hesitate to curb the Clinton administration's objectives on issues such as international tribunals or humanitarian law. During the Kosovo debate, Congress was characterised by a vast array of opinions, most of which caused divisions within, rather between parties. As a consequence, the mechanism of partisan politics did not materialise, with lawmakers substantially incapable of developing a clear stance in favour of or against the norm.

HI's fuzzy definition and scant international recognition has led various scholars and state leaders to considering the concept as merely a manifestation of Western interests. ${ }^{145}$ For this reason, many analyses on the issue have presented Operation Allied Force as essentially motivated by the necessity to reaffirm the role of NATO in Southeast Europe. ${ }^{146}$ Since at least E. H. Carr's critique of the doctrine of the 'harmony of interests', political realism has tended to interpret processes of state invocation of international norms as excuses to 'clothe [its] own interest in the guise of a universal interest for the purpose of imposing it on the rest of the world'. ${ }^{147}$ This article does not aim to refute this argument. Powerful states often provide interpretations of norms that fit their national interests, especially when they involve the commitment of military force. President Clinton implicitly recognised this point by arguing that emergent and partially undefined norms are more appropriate instruments of action for a superpower with global responsibilities: 'Too much precision in regard the use of force can inhibit flexibility and send contrary messages abroad and at home. ${ }^{\prime 48}$ This meant that the emergent status of HI did not allow to identify in advance and in an institutionalised way the conditions under which to invoke it. It was for political leaders to selectively decide when humanitarian action was legitimate and necessary. 
Nevertheless, structural approaches locating the cause of US behaviour in the context of a country's national interest provide scant insight on how competing interpretations of similar normative frameworks can shape the domestic debates of a country at specific points in time. This article did not aim to measure whether intervention in Kosovo depended more on national interests or moral values. ${ }^{149}$ It has rather analysed how both sets of arguments reached the domestic context, and how relevant actors competed to impose different interpretations of the US role in humanitarian crises.

This approach is useful to appreciate the variation in the way the US has dealt throughout time with norms that demand the use of force for humanitarian reasons. The favourable US position on $\mathrm{HI}$ at the end of the 1990s was the result of the interpretative action of the Clinton administration. Changing leadership in the White House and in the relevant foreign policy agencies can reverse this result. Different presidents, for example Barack Obama, have expressed less interventionist and also openly sceptical positions on the issue of committing US forces for the sake of human rights. Conceptualising national interests and foreign policy ideas as merely depending on the distribution of power does not help us understand how they can shift as a function of debates and political struggles that take place at the domestic level.

Finally, the analysis invites further reflection on the study of international norms and the processes that can lead to their consolidation or decline. Emergent and contested norms are more subject to invocation by powerful states because they can be more easily moulded according to specific interests and values. Their recognition can be occasionally accompanied by the invocation of a 'logic of emergency' that would allow for exceptional derogations from existing international law. For this reason, vague and undefined norms are more subject to the risk of being invoked or rejected in arbitrary ways. This could also be seen during the 2003 intervention in Iraq, which despite being waged by a different administration, was justified by a similar mix of humanitarian and strategic arguments, in the attempt to provide legitimacy to a military operation based on a limited legal basis. A world in which norms are not codified by clear and agreed upon procedures to operate them is likely to generate more conflicts of interpretation and more ambiguity in their implementation. In this sense, the re-conceptualisation of $\mathrm{HI}$ in terms of R2P represents a positive development for supporters of intervention, although, as demonstrated by recent examples of state reluctance to use force in the Middle East or North Africa and by the many disagreements which emerged at the World Summit Outcome in 2005, the effort to make intervention a consolidated norm of today's international system still has a long way to go.

\section{Notes}

1. William J. Clinton, 'Remarks on Returning from Camp David', Weekly Compilation of Presidential Documents 35, no. 2 (22 March 1999): 490.

2. Alex J. Bellamy, Responsibility to Protect: The Global Effort to End Mass Atrocities (Cambridge: Polity Press, 2009).

3. Martha Finnemore and Kathryn Sikkink, 'International Norm Dynamics and Political Change', International Organization 52, no. 4 (1998): 887-917.

4. Sydney Blumenthal, The Clinton Wars (New York: Farrar, Straus and Giroux, 2003); Ivo H. Daalder and Michael E. O'Hanlon, Winning Ugly: NATO's War to Save Kosovo (Washington, DC: Brookings Institution Press, 2000).

5. Judith Goldstein et al., 'Introduction: Legalization and World Politics', International Organization 54, no. 3 (Summer 2000): 385-99. 
6. Miles Kahler, 'Conclusion: The Causes and Consequences of Legalization', International Organization 54, no. 3 (Summer 2000): 680.

7. Tim Dunne, Inventing International Society: A History of the English School (London: Palgrave, 1998), 186; see also, Christian Reus-Smit, The Moral Purpose of the State: Culture, Social Identity, and Institutional Rationality in International Relations (Princeton, NJ: Princeton University Press, 1999), 134.

8. Alan Bryman, Social Research Methods (Oxford: Oxford University Press, 2012), 380.

9. Alexander L. George and Andrew Bennett, Case Studies and Theory Development in the Social Sciences (Cambridge, MA: MIT Press, 2005), 210.

10. Cit. See also Jeffrey T. Checkel, 'Process-Tracing', in Qualitative Methods in International Relations: A Pluralist Guide, ed. Audie Klotz and Deepa Prakash (London: Palgrave, 2008), 114-27.

11. Bryman, Social Research Methods, 542-63.

12. Thomas Risse, “Let's Argue!" Communicative Action in World Politics', International Organization 54, no. 1 (Winter 2000): 1-39.

13. Iver B. Neumann, 'Discourse Analysis', in Qualitative Methods in International Relations, ed. Klotz and Saprash, 61-77.

14. Madeleine Albright, Madame Secretary (New York: Miramax, 2003), 381.

15. Security Council Resolution 1199, S/RES/1199 (23 September 1998).

16. Javier Solana, 'Statement to the Press by the Secretary General following Decision on the ACTORD', 13 October 1998.

17. Friedrich V. Kratochwil, 'How Do Norms Matter?', in The Role of Law in International Politics: Essays in International Relations and International Law, ed. by Michael Byers (Oxford: Oxford University Press, 2000), 35-68.

18. Gideon Rose, 'Neoclassical Realism and Theories of Foreign Policy', World Politics 51, no. 1 (October 1998): 144-72; Jeffrey Legro and Andrew Moravcsik, 'Is Anybody Still a Realist?', International Security 24, no. 1 (Fall 1999): 5-55.

19. Margaret E. Keck and Kathryn Sikkink, Activists beyond Borders (Ithaca, NY: Cornell University Press, 1998), 4.

20. Michael Williams, 'Why Ideas Matter in International Relations: Hans Morgenthau, Classic Realism, and the Moral Construction of Power Politics', International Organization 58 (Fall 2004): 633-65.

21. Alexander Wendt, Social Theory of International Politics (Cambridge: Cambridge University Press, 1999).

22. Jeffrey W. Legro, 'Which Norms Matter? Revisiting the Failure of Internationalism', International Organization 51, no. 1 (Winter 1997): 31-63.

23. Kathryn Sikkink and Martha Finnemore, 'Taking Stock: The Constructivist Research Program in International Relations and Comparative Politics', Annual Review of Political Science 4 (2001): 397.

24. Christian Reus-Smit, 'Constructivism and the English School', in Theorising International Society (London: Palgrave, 2009), 63; Peter J. Katzenstein, Cultural Norms and National Security: Police and Military in Postwar Japan (Ithaca, NY: Cornell University Press, 1996).

25. Jeffrey T. Checkel, 'International Norms and Domestic Politics: Bridging the RationalistConstructivist Divide', European Journal of International Relations 3, no. 4 (1997): 477.

26. James N. Rosenau, Domestic Sources of Foreign Policy (New York: The Free Press, 1967).

27. Thomas Risse, Stephen C. Ropp, and Kathryn Sikkink, eds, The Power of Human Rights: International Norms and Domestic Change (Cambridge: Cambridge University Press, 1999).

28. James G. March and Johan P. Olsen, 'The Institutional Dynamics of International Political Orders', International Organization 52, no. 4 (Autumn 1998): 943-69.

29. Ethan A. Nadelmann, 'Global Prohibition Regimes: The Evolution of Norms in International Society', International Organization 44, no. 4 (Autumn 1990): 480.

30. John Peterson, 'In Defence of Inelegance: IR Theory and Transatlantic Practice', International Relations 20, no. 1 (March 2006): 8. 
31. Brian C. Rathbun, Partisan Interventions: European Party Politics and Peace Enforcement in the Balkans (Ithaca and London: Cornell University Press, 2004), 7.

32. Thomas Risse, 'To Euro or Not to Euro? The EMU and Identity Politics in the European Union', European Journal of International Relations 5, no. 2 (1999): 147-87.

33. Thomas W. Graham, 'Public Opinion and U.S. Foreign Policy Decision Making', in The New Politics of American Foreign Policy, ed. David Deese (London: Palgrave, 1994), 190-215.

34. Peter Viggo Jakobsen, 'National Interest, Humanitarianism or CNN: What Triggers UN Peace Enforcement after the Cold War?', Journal of Peace Research 33, no. 2 (1996): 205-15.

35. Program on International Policy Attitudes, 'Americans on Kosovo: A Study of Public Attitudes', 27 May 1999.

36. Sikkink and Keck, Activists beyond Borders; Sanjeev Khagram, James V. Ricker, Kathryn Sikkink, eds, Restructuring World Politics: Transnational Movements, Social Networks, and Norms (Minneapolis: University of Minnesota Press, 2002).

37. Christopher Hill, The Changing Politics of Foreign Policy (New York: Palgrave, 2003), 51-66.

38. Finnemore and Sikkink, 'International Norms Dynamics and Political Change', 897.

39. Peter Katzenstein, The Culture of National Security: Norms and Identity in World Politics (New York: Columbia University Press, 1996), 5.

40. Khagram, Riker, and Sikkink, Restructuring World Politics, 14.

41. Martha Finnemore, National Interests in International Society (Ithaca, NY: Cornell University Press, 1996), 22.

42. Antje Wiener, 'Contested Meanings of Norms: A Research Framework', Comparative European Politics 5 (2007): 1.

43. Antonio Cassese, 'Ex Iniuria Ius Oritur: Are We Moving Toward International Legitimation of Forcible Humanitarian Countermeasures in the World Community?', European Journal of International Law 10 (1999): 23-30.

44. Danilo Zolo, Chi dice umanita': Guerra, diritto e ordine globale (Torino: Einaudi, 2000), 83.

45. Kai Ambos, 'Comment on Bruno Simma, NATO, the UN, and the Use of Force: Legal Aspects', European Journal of International Law 10, no. 1 (1999).

46. Robert Jackson, The Global Covenant: Human Conduct in a World of States (Oxford: Oxford University Press, 2000), 291.

47. Alex J. Bellamy, Sara E. Davies, and Luke Glanville, eds, The Responsibility to Protect and International Law (Leiden, Boston: Martinus Nijhoff Publishers, 2011).

48. Risse, Ropp, and Sikkink, The Power of Human Rights, 15.

49. In Larger Freedom: Towards Development, Security, and Human Rights for all Report of the Secretary-General (United Nations General Assembly, Fifty-ninth Session, 21 March 2005).

50. Ian Budge and David McKay, eds, Developing Democracy: Comparative Research in Honour of J. F. P. Blondel (London: Sage Publications, 1994); Sergio Fabbrini, Compound Democracies: Why the United States and Europe are Becoming Similar (Oxford: Oxford University Press, 2007), Chapter 5.

51. Program on International Policy Attitudes, cit. 13.

52. Amnesty International, 'Concerns in Europe January/June 1998', EUR 01/02/98, September 1998.

53. Human Rights Watch, 'Human Rights Watch Recommendations on the OSCE Kosovo Verification Mission', 20 October 1998.

54. Amnesty International USA, 'Amnesty International Writes to NATO's Secretary General', News Service 092/99, AI Index Eur70/60/99, 11 May 1999.

55. Amnesty International USA, 'Statement by Pierre Sane Secretary General', Amnesty International, News Service 125/98 London, 30 June 1998.

56. Statement by Jeane Kirkpatrick, American Enterprise Institute, Comm. International Relations, H. R. Rep. 106-1049, 106th Congress, First Session (March 1999), 7-8.

57. John R. Bolton, 'Adult Supervision ... Needed on Stage', American Enterprise Institute, 23 February 1999.

58. John R. Bolton, 'Clinton Meets "International Law" in Kosovo', American Enterprise Institute, 5 April 1999. 
59. James H. Anderson, 'No Ground Troops in Kosovo', The Heritage Foundation Executive Memorandum no. 555 (8 October 1998).

60. James H. Anderson, 'Avoiding Another Balkan Quagmire in Kosovo', The Heritage Foundation Executive Memorandum no. 572 (12 February 1999).

61. 'Statement of Doug Bandow, Cato Institute, Comm. International Relations, H.R. Rep'. 1061053, 106th Congress, First Session (10 March 1999), 45.

62. Kim R. Holmes, 'No Ground War in Kosovo', The Heritage Foundation Backgrounder 1278 (22 April 1999).

63. Gary T. Dempsey, 'Washington's Kosovo Policy: Consequences and Contradictions', Cato Institute, Policy Analysis 321 (8 October 1998).

64. 'Statement by Albanian American Civic League Regarding Situation in Kosovo', H.R. 106th Congress, First Session, (7 January 1999), E 59.

65. Comm. International Relations, H.R. 106th Congress, First Session (10 February 1999), 19.

66. Ivo H. Daalder, 'NATO, the UN, and the Use of Force' (United Nations Association of the United States of America, March 1999).

67. Rathbun, Partisan Interventions; Risse, 'To Euro or Not to Euro?'

68. Edward C. Luck, 'The United States, International Organizations, and the Quest for Legitimacy', in Multilateralism and U.S. Foreign Policy: Ambivalent Engagement, ed. Shepard Foreman, Stewart Patrick, and Joanne J. Myers (Boulder, CO: Lynne Rienner, 2002), 47-74.

69. Louis Fisher, Presidential War Power (Lawrence: University Press of Kansas, 2004).

70. David W. Rhode, 'Partisan Leadership and Congressional Assertiveness in Foreign and Defense Policy', in The New Politics of American Foreign Policy, ed. David Deese (New York: San Martin's Press, 1994), 76-101.

71. Ryan C. Hendrickson, The Clinton Wars: The Constitution, Congress and War Powers (Nashville: Vanderbilt University Press, 2002), 117.

72. House of Representatives, 105th Congress, Second Session (17 March 1998): H 1202.

73. Senate, 105th Congress, Second Session (17 June 1998): S 6463.

74. Senate, 105th Congress, Second Session (7 October 1998): S 11651.

75. House of Representatives, 106th Congress, First Session (24 March 1999): H 1661.

76. House of Representatives, 105th Congress, Second Session (1 October 1998): H 9212.

77. Senate, 105th Congress, Second Session (2 October 1998): S 11328.

78. Senate, 105th Congress, Second Session (17 June 1998): S 6464.

79. House of Representatives, 105th Congress, Second Session (1 October 1998): H 9191.

80. House of Representatives, 106th Congress, First Session (9 February 1999): H 529.

81. Comm. International Relations, H.R. 106th Congress, First Session (10 February 1999): 24.

82. House of Representatives, 106th Congress, First Session (28 April 1999): H 2430.

83. Senate, 106th Congress, First Session (23 February 1999): S 1772.

84. Senate, 106th Congress, First Session (22 March 1999): S 3055.

85. Hendrickson, The Clinton Wars, 135.

86. For example, Senate, 105th Congress, Second Session (8 October 1998): S 11896-S 11992.

87. Hendrickson, The Clinton Wars, 123.

88. Congressional Quarterly Almanac, 106th Congress, Second Session, 23 March 1999.

89. Senate, 106th Congress, First Session (23 March 1999): S 3110.

90. US Code, Title 50, Chapter 33, 'War Powers Resolution', 7 November 1973.

91. House of Representatives, 106th Congress, First Session (28 April 1999): H 2400.

92. House of Representatives, 106th Congress, First Session (28 April 1999): H 2441.

93. Senate, 106th Congress, First Session (23 March 1999): S 3110.

94. House of Representatives, 106th Congress, First Session (28 April 1999): H 2446.

95. House of Representatives, 106th Congress, First Session (6 May 1999): H 2879.

96. Cit. H 2891.

97. Andrew Taylor, 'Appropriations: Paying for the Kosovo Air War: How Much Is Too Much?', CQ Weekly Online (1 May 1999).

98. Gebe Martinez, 'Campbell Maneuvers to Force an Ambivalent Congress to Choose', Congressional Quarterly Weekly, 24 April 1999. 
99. Michael Dobbs, Madeleine Albright: A Twentieth-Century Odyssey (New York: Holt, 1999), 421.

100. William G. Hyland, Clinton's World: Remaking American Foreign Policy (Westport, London: Praeger, 1999), 21-2.

101. Albright, Madame Secretary, 383.

102. Cit. in David Halberstam, War in a Time of Peace (New York: Scribner, 2001), 441.

103. Albright, Madame Secretary, 395.

104. Halberstam, War in a Time of Peace, 422.

105. Wesley Clark, Waging Modern War: Bosnia, Kosovo and the Future of Combat (New York: Public Affairs, 2001), 119-20.

106. William J. Clinton, 'Joint Statement on the Situation in Kosovo', Weekly Compilation of Presidential Documents 34, no. 2 (2 September 1998): 1693.

107. Barton Gellman, 'The Path to Crisis: How the United States and Its Allies Went to War', Washington Post, 18 April 1999.

108. Daalder and O'Hanlon, Winning Ugly, 72.

109. Louis Hartz, The Liberal Tradition in America: An Interpretation of American Political Thought since the Revolution (New York: Harvest, 1955); Seymour Martin Lipset, The First New Nation: The United States in Historical and Comparative Perspective (New York: Norton, 1979).

110. Stewart, Foreman, and Myers, Multilateralism and U.S. Foreign Policy, 7-8.

111. Nathalie Kaufman, Human Rights Treaties and the Senate: A History of Opposition (Chapel Hill: The University of North Carolina Press, 1990); Jason Ralph, Defending the Society of States: Why America Opposes the International Criminal Court and its Vision of World Society (Oxford: Oxford University Press, 2007).

112. Fisher, Presidential War Power.

113. Sarah B. Sewall and Carl Kaysen, eds, The United States and the International Criminal Court: National Security and International Law (Lanham, MD: Rowman \& Littlefield Publishers, 2000), 3.

114. William Cohen, 'The Report of the Quadrennial Defense Review', May 1997.

115. The White House, 'A National Security Strategy for a New Century', May 1997.

116. 'The Report of the Quadrennial Defense Review', May 1997.

117. John Dumbrell, 'Was There a Clinton Doctrine? President Clinton's Foreign Policy Reconsidered', Diplomacy and Statecraft 13 (2002): 43-56.

118. Strobe Talbott, 'Democracy and the National Interest', Foreign Affairs 75, no. 6 (November/ December 1996): 47.

119. Samuel E. Berger, 'A Foreign Policy Agenda for the Second Term', Center for Strategic and International Studies, Washington, DC, 27 March 1997.

120. Dumbrell, 'Was There a Clinton Doctrine?', 49.

121. 'Presidential Decision Directive 25: Reforming Multilateral Peace Operations', Executive Summary, 5 May 1994.

122. Cit. See also James McCormick, 'Assessing Clinton's Foreign Policy at Midterm', Current History 94 (November 1995): 370-1.

123. David Lake, 'From Containment to Enlargement', Johns Hopkins University, Washington, DC, 21 September 1993.

124. William S. Cohen, 'Annual Report to the President and the Congress', April 1997.

125. Madeleine K. Albright, Anthony Lake, and Wesley Clark, 'The Clinton Administration Policy on Reforming Multilateral Peace Operations', U.S. Department of States Dispatch 5, no. 20 (16 May 1994): 315.

126. David Lake, 'American Power and American Diplomacy', U.S. State Department Dispatch 5, no. 46 (14 November 1994).

127. Risse, 'Let's Argue!', 7.

128. Kenneth H. Bacon, 'Department of Defense News Briefing', 20 April 1999.

129. 'Statement of the Honorable Walter Slocombe, Under-Secretary of Defense for Policy', Comm. International Relations H.R. 105th Congress, Second Session (23 July 1998): 12. 
130. Clinton, 'Letter to Congressional Leaders Reporting on the Decision to Send Certain United States Force to Macedonia and Albania', Weekly Compilation of Presidential Documents 35, no. 14 (12 April 1999): 580.

131. Statement of the Hon. Walter Slocombe, 12.

132. Under Secretary of Defense for Policy Slocombe and Ambassador Vershow, 'Background Briefing', Vilamoura, Portugal, 24 September 1998.

133. Press Briefing by National Security Advisor Sandy Berger, 25 March 1999, in John T. Woolley and Gerhard Peters, The American Presidency Project [online]. Santa Barbara, CA. http:// www.presidency.ucsb.edu/ws/?pid=47833.

134. Clinton, 'Letter to Congressional Leaders Reporting on Airstrikes Against the Federal Republic of Yugoslavia', Weekly Compilation of Presidential Documents 35, no. 21 (31 May 1999): 990.

135. 'Statement of Hon. Albright, Secretary of State', Comm. International Relations H.R. 106th Congress, First Session (21 April 1999): 7.

136. 'Statement of Hon. Albright, Secretary of State', Comm. Foreign Relations Senate, 106th Congress, First Session (20 April 1999): 17.

137. Hendrickson, The Clinton Wars, 138-59.

138. Nicholas J. Wheeler, Saving Strangers: Humanitarian Intervention in International Society (Oxford: Oxford University Press, 2000), 167-9.

139. Aidan Hehir, Humanitarian Intervention: An Introduction (London: Palgrave, 2010), 233. See also, Aidan Hehir, Humanitarian Intervention after Kosovo: Iraq, Darfur, and the Record of Global Civil Society (London: Palgrave, 2008); David Chandler, From Kosovo to Kabul (and Beyond): Human Rights and International Intervention (London: Pluto, 2006).

140. Louis Fisher, 'Deciding on War against Iraq: Institutional Failures', Political Science Quarterly 118, no. 3 (2003): 407.

141. United Nations, Statement by President Bush, United Nations General Assembly, New York, 12 September 2002; President George W. Bush, 'Address to the Nation on Iraq from Cincinnati', Ohio, 7 October 2002, Daily Comp. Pres. Docs, 2009, 1716-20.

142. Hehir, Humanitarian Intervention, 232; Thomas G. Weiss, 'The Sunset of Humanitarian Intervention? The Responsibility to Protect in a Unipolar Era', Security Dialogue 35, no. 2 (June 2004): 135-53.

143. Alex J. Bellamy, “Whither the Responsibility to Protect?" Humanitarian Intervention and the 2005 World Summit', Ethics and International Affairs 20, no. 2 (Summer 2006): 143-69.

144. Fisher, Presidential War Powers.

145. Declaration of the South Summit, La Havana (10-14 April 2000). http://www.nam.gov.za/ documentation/southdecl.htm.

146. See note 4 .

147. Ralph, Defending the Society of States, 208.

148. Cit. in Brenda Connors, 'Mission Possible: Making United Nations Peace Operations More Effective', Paper Submitted to the Faculty of the Naval War College, Newport RI (17 June 1994): 10.

149. Jean-Marc Coicaud and Nicholas J. Wheeler, National Interest and International Solidarity (New York: United Nations University Press, 2008).

\section{Disclosure statement}

No potential conflict of interest was reported by the author.

\section{Note on contributor}

Andrea Betti is Professor of International Politics in the Department of International Relations at the Pontificia Universidad Comillas in Madrid. He holds a PhD in International Relations from the University of Trento (Italy) with a dissertation on American and British foreign policies towards Responsibility to Protect and international criminal jurisdictions. His main interest is in Theory of International Relations with a particular focus on how domestic actors socially construct foreign policy discourse in regard to international institutions, norms, and ideas. 